\title{
The Different Faces of Arabidopsis arenosa-A Plant Species for a Special Purpose
}

\author{
Żaneta Gieroń, Krzysztof Sitko*(D) and Eugeniusz Małkowski *(D) \\ Plant Ecophysiology Team, Faculty of Natural Sciences, University of Silesia in Katowice, 28 Jagiellońska Str., \\ 40-032 Katowice, Poland; zgieron@us.edu.pl \\ * Correspondence: krzysztof.sitko@us.edu.pl (K.S.); eugeniusz.malkowski@us.edu.pl (E.M.)
}

\begin{abstract}
The following review article collects information on the plant species Arabidopsis arenosa. Thus far, $A$. arenosa has been known as a model species for autotetraploidy studies because, apart from diploid individuals, there are also tetraploid populations, which is a unique feature of this Arabidopsis species. In addition, $A$ arenosa has often been reported in heavy metal-contaminated sites, where it occurs together with a closely related species $A$. halleri, a model plant hyperaccumulator of $\mathrm{Cd}$ and $\mathrm{Zn}$. Recent studies have shown that several populations of $A$. arenosa also exhibit $\mathrm{Cd}$ and Zn hyperaccumulation. However, it is assumed that the mechanism of hyperaccumulation differs between these two Arabidopsis species. Nevertheless, this phenomenon is still not fully understood, and thorough research is needed. In this paper, we summarize the current state of knowledge regarding research on $A$. arenosa.
\end{abstract}

Keywords: Arabidopsis arenosa; hyperaccumulation; autopolyploidy

Citation: Gieroń, Ż.; Sitko, K.; Małkowski, E. The Different Faces of Arabidopsis arenosa-A Plant Species for a Special Purpose. Plants 2021, 10, 1342. https://doi.org/10.3390/ plants10071342

Academic Editor: Roberto De Michele

Received: 21 May 2021

Accepted: 28 June 2021

Published: 30 June 2021

Publisher's Note: MDPI stays neutral with regard to jurisdictional claims in published maps and institutional affiliations.

Copyright: (c) 2021 by the authors. Licensee MDPI, Basel, Switzerland. This article is an open access article distributed under the terms and conditions of the Creative Commons Attribution (CC BY) license (https:// creativecommons.org/licenses/by/ $4.0 /)$.

\section{Arabidopsis arenosa-General Information}

Arabidopsis arenosa, previously known as Cardaminopsis arenosa, is a species of flowering plants in the family Brassicaceae, which includes two subspecies: A. arenosa ssp. arenosa and $A$. arenosa ssp. borbasii $[1,2]$. A. arenosa is a model plant species used to study the natural phenomenon of autopolyploidyzation, which means the duplication of the whole genome within one species, in contrast to allopolyploids, which are the result of genome duplication via interspecies hybridisation. A. arenosa is more closely related to its diploid sister taxa A. lyrata and to $A$. halleri (metal hyperaccumulator), than to $A$. thaliana. Although $A$. arenosa and $A$. halleri are closely related, studies which compare both species are still scarce [2-5]. A distinguishing feature of this species is its natural occurrence both in a diploid $(2 \mathrm{n}=2 \mathrm{C}=16)$ and tetraploid $(2 \mathrm{n}=4 \mathrm{C}=32)$ form, in contrast to $A$. halleri, in which only diploid forms $(2 n=2 C=16)$ were found [6-9].

A. arenosa grows in subfertile soils. It has been observed in sandy areas, dry grasslands and roadsides. Plants of this species are present in many sites in Europe; however, their location differs depending on the level of ploidy, because tetraploid forms were noted in Slovenia, France and Belgium to the west and north of the Carpathians, while diploid forms have been found in South-East Europe, the Balkan Peninsula and northern Hungary. Moreover, the Carpathian mountain arch, in particular the western Carpathians, is one of the two contact zones where both diploid and tetraploid populations co-exist. The second contact zone of both cytotypes is in the Slovenian Forealps [7,10-12]. A. arenosa, similarly to A. halleri, is a pseudo-metallophyte [13-16], which is the species used to study adaptations to the environments that are highly contaminated with heavy metals $[3,4,17,18]$. Both species can be commonly found on metalliferous and non-metalliferous sites [18-22]. The pictures of both diploid and tetraploid forms of $A$. arenosa are presented in Figure 1. 

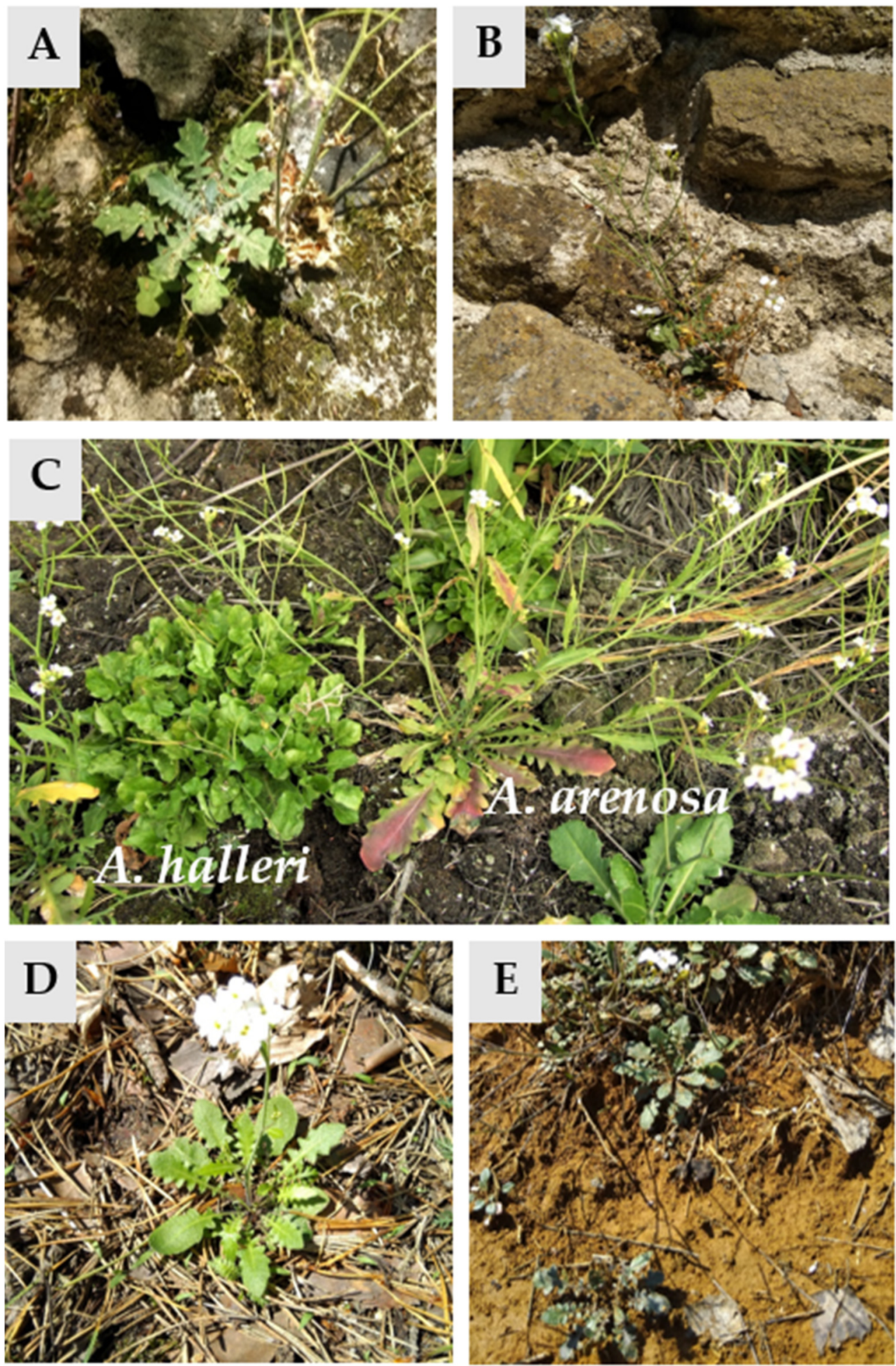

Figure 1. Pictures of Arabidopsis arenosa in situ. (A)—diploid (2C) from Csesznek, Hungary; (B) diploid (2C) from Szigliget, Hungary; (C) - comparison of A. arenosa (4C) and A. halleri (2C) in Piekary Śl., Poland; (D)—tetraploid (4C) from Klucze, Poland; (E)—tetraploid (4C) from Dołki, Poland.

A. arenosa is a biennial or short-lived perennial herb. The leaves are arranged in a rosette at the ground level, and no runners form from the rosette. The shape of the leaf blade is obovate to oblanceolate, pinnatifid to lyrate-pinnatifid and with three to eleven lateral lobes on each side. The stems of this plant species are erect, simple, or with few or more branches from the base. A. arenosa produces tiny flowers whose petals are white 
to lavender, obovate, obtuse or cut at the apex [2]. The siliques of $A$. arenosa are always smooth and raised up, in contrast to $A$. halleri, in which a narrowing reflecting the seeds occurs (Figure 2). Moreover, the pedicles in A. arenosa are at an acute angle to peduncle, whereas in $A$. halleri they are almost perpendicular (Figure 2). The period of flowering and fruit production is from April to July or, rarely, to August.
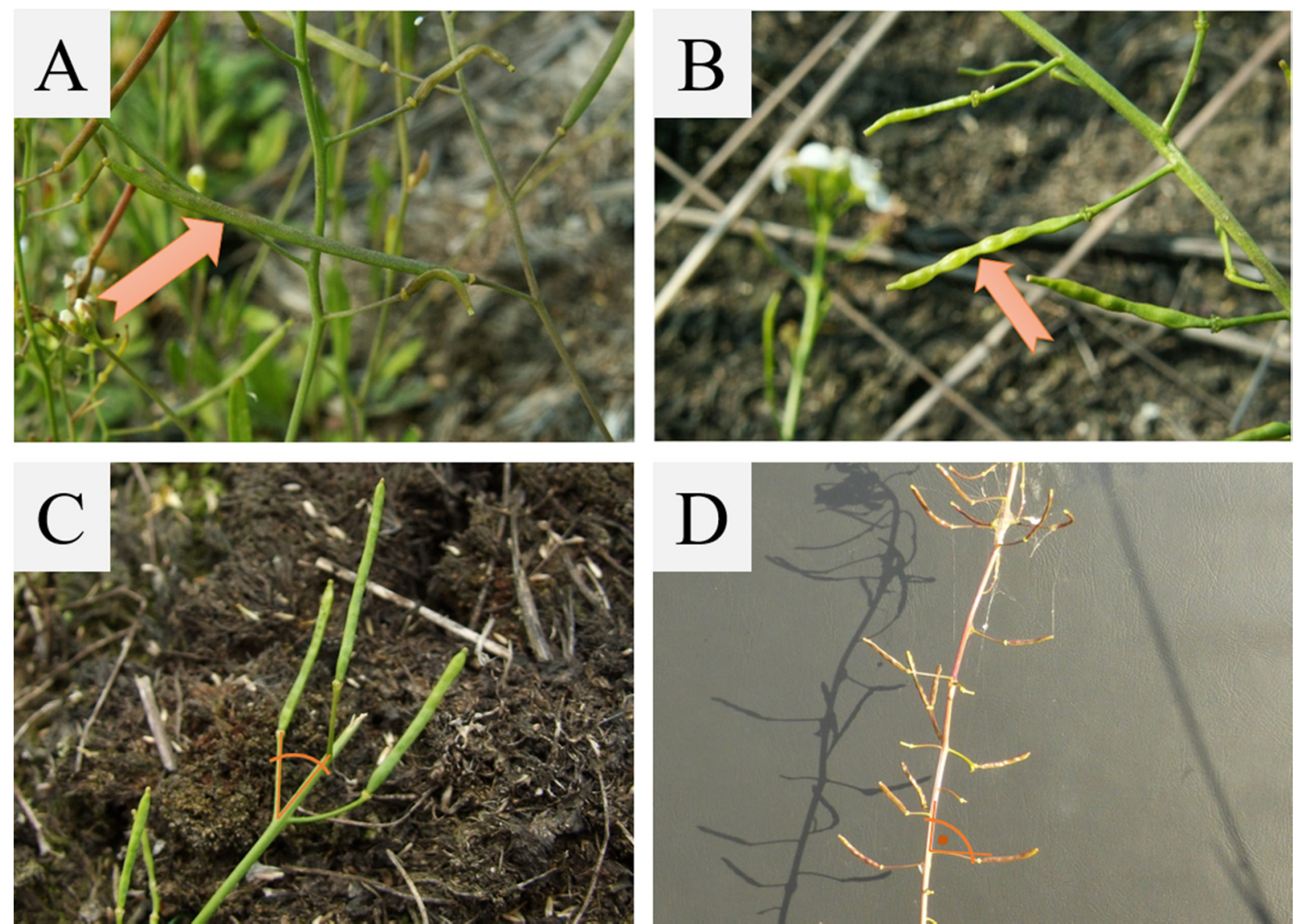

Figure 2. Pictures of the siliques of $A$. arenosa $(\mathbf{A}, \mathbf{C})$ compared to the siliques of $A$. halleri $(\mathbf{B}, \mathbf{D})$. On picture $(\mathbf{B})$, the arrow indicates a characteristic narrowing that is not present in $A$. arenosa siliques. Pictures $(\mathbf{C}, \mathbf{D})$ show the differences in the location of the pedicles relative to the peduncles in both species.

\section{Adaptation to Autopolyploidy}

Arabidopsis arenosa exists in nature as diploid and autotetraploid populations. The ability to duplicate the whole genome of autotetraploid populations of $A$. arenosa is closely linked to the adaptation of tetraploids to duplication without errors in meiosis; thus, most importantly, avoiding the formation of multivalents or univalents, which cause sterility [23-25]. Tetraploid individuals of $A$. arenosa perform diploid-like chromosome pairings at meiosis, where bivalents are selected randomly from four homologs $[8,12,26]$. A comparative analysis of the genomes of diploid and autotetraploid populations allowed one to distinguish a group of 44 genes with divergent selection between ploidy levels, responsible for the ability of $A$. arenosa to perform stable meiosis and, consequently, to create subsequent generations of autotetraploid populations of this species. This set of genes mainly affects the meiotic crossover initiation pathway, but is also involved in other functions, such as chromosomal cohesion or segregation, chromatin structure, DNA repair and transcriptional regulation $[8,12,23,26]$. This set includes ASYNAPTIC 1 and 3 (ASY1 and $A S Y 3$ ) genes, which encode core components of the chromosome axis and present a strong signature of adaptive evolution focused on a mutation that changes a single amino acid $[8,12,24]$. Other genes in this important group are SISTER CHROMATID COHESION2 
(SCC2), responsible for encoding the adherin loading cohesin during meiosis [26,27], as well as STRUCTURAL MAINTENANCE OF CHROMOSOMES 3, 5 and 6 (SMC3, SMC5 and SMC6), genes related to meiosis, which show signatures of selective sweeps $[12,26,28]$. Moreover, the meiotic genes show the strongest features of introgression resistance in tetraploid populations; that is, increased divergence between cytotypes, with commitment limited diversity in tetraploids, and tetraploid monophy in the contact zones of both cytotypes. It follows from the necessity of exclusion of the introduction of diploid-like meiotic alleles to tetraploids, which would result in the formation of multivalents [29,30].

The ability to duplicate the whole genome, and thus the ability of autotetraploidyzation, has certain consequences. Results of a recent study support the possibility that it is possible to overcome the adaptation obstacles caused by reduced selection efficiency, due to increased mutational input [31,32]. This is confirmed by the results of comparative genome analyses of diploid and tetraploid populations, which show that in tetraploid populations, even the increased masking of beneficial mutations is not sufficient to slow the adaptation process, due to the higher number of non-synonymous polymorphisms fixed by positive selection [29]. Additionally, it has been shown that autopolyploidy may increase genome flexibility, allowing plants to adapt to more heterogeneous conditions. As a result, tetraploid populations of $A$. arenosa inhabit sites polluted by human activities, going beyond the natural areas inhabited by diploid ancestors $[25,29,33]$.

\section{Arabidopsis arenosa and Heavy Metals}

Arabidopsis arenosa is considered to be a pseudo-metallophyte, that is, a plant species that inhabits both metalliferous and non-metalliferous sites [3,18,22]. For many years, this species has been considered as an excluder, a plant that is able to survive on metalliferous soils, maintaining a physiological content of zinc $(\mathrm{Zn})$ and low cadmium $(\mathrm{Cd})$ in its above-ground tissues in plants growing in situ [6,34]. Nevertheless, the first reports began to appear about the ability of several populations of $A$. arenosa to hyperaccumulate $\mathrm{Zn}[4,22,35]$, according to the generally accepted definition proposed by Van der Ent and colleagues [36]. The term hyperaccumulator is defined as plants that are able to take up and accumulate a specific concentration of heavy metals from the soil. It should also be emphasised that in hyperaccumulators, heavy metals should be easily transported from the root to the shoot for their accumulation in above-ground organs without any observable symptoms of phytotoxicity being displayed [14,34,36-39]. The hyperaccumulation of $\mathrm{Zn}$ was first described for Nocceaea caerulescens, also from the family Brassicaceae, in 1865 [40]. Currently, approximately 721 plant species have been reported that show HM hyperaccumulation. This number accounts for $0.2 \%$ of all known plant species, and the new hyperaccumulator species are being reported [34,36,37,40-43]. From this group of plants, $\mathrm{Cd}$ and $\mathrm{Zn}$ hyperaccumulation was shown mainly in the Brassicaceae family, and in a few other species from other families, for example, Crassulaceae (Sedum alfredii, Sedum plumbizincicola) [44-46]. In previous studies, Nadgórska-Socha et al. [47] showed that the content of metals such as $\mathrm{Cd}, \mathrm{Zn}, \mathrm{Pb}, \mathrm{Fe}$ and $\mathrm{Mn}$ is considerably higher in $A$. arenosa compared to Plantago lanceolata and Plantago major grown in the metal-contaminated soils in situ. Moreover, in A. arenosa, the translocation factor (the ratio between the metal concentration in shoots to the metal concentration in roots) was above 1 for $\mathrm{Cd}$ and $\mathrm{Zn}$, which suggested the hyperaccumulation of both metals [47]. Recent studies confirmed the ability of $A$. arenosa to hyperaccumulate $\mathrm{Cd}$ and $\mathrm{Zn}$ [35]. In this study, they showed a higher ability to hyperaccumulate $\mathrm{Zn}$ than $\mathrm{Cd}$ in $A$. arenosa, as this feature for $\mathrm{Zn}$ has been proven in five out of six studied metallicolous populations. In contrast, $\mathrm{Cd}$ hyperaccumulation was found only in three metallicolous populations [35]. In addition, the adaptation of another two populations of $A$. arenosa from southern Poland to grow in HM-contaminated soil was shown. However, the capability for the hyperaccumulation of $\mathrm{Zn}$ or $\mathrm{Cd}$ by both populations was not presented [3].

Populations of $A$. arenosa in various habitats show specific morphological features. For example, the length of the leaves of plants grown on a copper $(\mathrm{Cu})$ mining heap was 
2.5 times smaller than the leaves of plants grown in non-contaminated soil. By contrast, the length of the roots of the seedlings from the heap was remarkably longer compared with the plants from the reference site $[15,48]$. Similarly, an A. arenosa population growing on a $\mathrm{Zn} / \mathrm{Pb}$ waste heap had smaller size, thicker and narrower leaves, with fewer trichomes. Moreover, the root test showed a higher tolerance to $\mathrm{Cd}, \mathrm{Zn}$ and $\mathrm{Pb}$ for the population from the heap compared to the reference population [18]. On the other hand, both the metallicolous (M) and non-metallicolous (NM) A. arenosa tetraploid plants growing in hydroponic solution without HMs displayed higher above-ground biomass compared to the A. halleri plants [22]. However, in Cd-containing media, a more significant decrease in biomass was observed in the NM population than in the M population of $A$. arenosa [22]. Root biomass also decreased by treatment with $\mathrm{Cd}$ by less than $50 \%$ in the M population and about $90 \%$ in the NM population compared to the control [22]. Similarly, the $\mathrm{Zn}$ treatment caused root growth limitation in both $A$. arenosa and A. halleri [4]. The presence of $\mathrm{Zn}$ can also increase the volume and root length of the hyperaccumulator plant, which has been shown for S. alfredii [49].

In general, photosynthesis in hyperaccumulator plants has been seldom investigated. As a result, the resistance of photosynthetic apparatus to the toxic effect of metals in this group of plants is poorly understood [50-52], in comparison with large amount of data on crop plants [53-58]. The studies of the photosynthetic apparatus parameters of $A$. arenosa in situ demonstrated the adaptability and high level of tolerance of the metallicolous population to HM. Nevertheless, NM populations had better PSII energy fluxes parameters compared to the $\mathrm{M}$ populations. However, the values of the parameters studied for a population from the extremely polluted area were closer to the NM populations than to the most $\mathrm{M}$ populations [35]. This may result from a considerable variation in the resistance of the photosynthetic apparatus to heavy metals between populations from metalliferous sites. In the case of $A$. arenosa plants from highly polluted sites in Piekary Ślakie (Poland), the exceptionally high resistance of the photosynthetic apparatus to metals was found. The photosynthesis parameters were similar to those in plants from the reference sites. However, such high resistance is not observed in all populations from metalliferous sites [35]. In $N$. caerulescens, $\mathrm{Cd}$ and $\mathrm{Zn}$ were accumulated mostly in the vacuoles of epidermal cells; in consequence, the metals were non-toxic for PSII. Exposure to $800 \mu \mathrm{M} \mathrm{Zn}$ or $40 \mu \mathrm{M} \mathrm{Cd}$ in a hydroponic experiment increased $\mathrm{Ca}^{2+}$ translocation to the above-ground parts and increased $\mathrm{Fe}^{3+}$ uptake as a PSII photoprotective mechanism [59]. A similar mechanism was found in A. halleri, but HMs were accumulated in the vacuoles of leaves' parenchyma [60]. A different reaction was demonstrated by Morina and Küpper [52] for A. halleri treated with $\mathrm{Cd}$, who found that $\mathrm{Cd}$ is mainly accumulated in the veins and reduces the distribution of Fe and $\mathrm{Zn}$ from the veins. However, no effect on the distribution of Ca was found. Thus, the disturbance in the leaf nutrient homeostasis after $\mathrm{Cd}$ treatment could be the main factor behind the progressive inhibition of the PSII reaction centers and the decrease in quantum yield of the electron transport [52]. There are no data about the mechanism of sequestration of HMs in $A$. arenosa leaves. It has been shown that the metallicolous population of A. arenosa exhibit similar values of chlorophyll $a$ fluorescence to the metallicolous $A$. halleri population: the HM hyperaccumulator. A significantly higher chlorophyll content index in the metallicolous and non-metallicolous A. arenosa populations compared to the $A$. halleri populations was also found. Moreover, the higher content of this pigment in $A$. arenosa compared to the metallicolous $A$. halleri population may indicate a better physiological status of this $A$. arenosa population [22].

Polyphenols, such as flavonols and anthocyanins, are generally recognized as molecules involved in stress protection in plants and have multiple functions in acclimation processes to an excessive amount of HMs [61,62]. It has been demonstrated in A. thaliana that anthocyanins play a major role in protecting against metal stresses [63]. Muszyńska et al. [64] showed that the enhanced accumulation of phenolic acids provides an efficient neutralization of metal-induced ROS in metallicolous ecotypes of Alyssum montanum. Furthermore, the accumulation of flavonols in leaves was a characteristic reaction of M-ecotypes of 
A. montanum during HM treatment [64]. Moreover, the higher level of anthocyanins content index has been reported in $A$. arenosa populations from metalliferous rather than non-metalliferous sites (Figure 3), indicating the increased tolerance of metallicolous populations to the toxic effects of HM [22,35]. However, the values of this parameter for M and NM A. arenosa populations were lower than for the M population of A. halleri [22]. Moreover, flavonols and anthocyanins have been shown to contribute significantly to the response to HM in hyperaccumulating and non-hyperaccumulating plant species, leading to enhanced metal antioxidant and chelating capacity [65]. The general comparison of metallicolous and non-metallicolous populations of A. arenosa is presented in Figure 3.

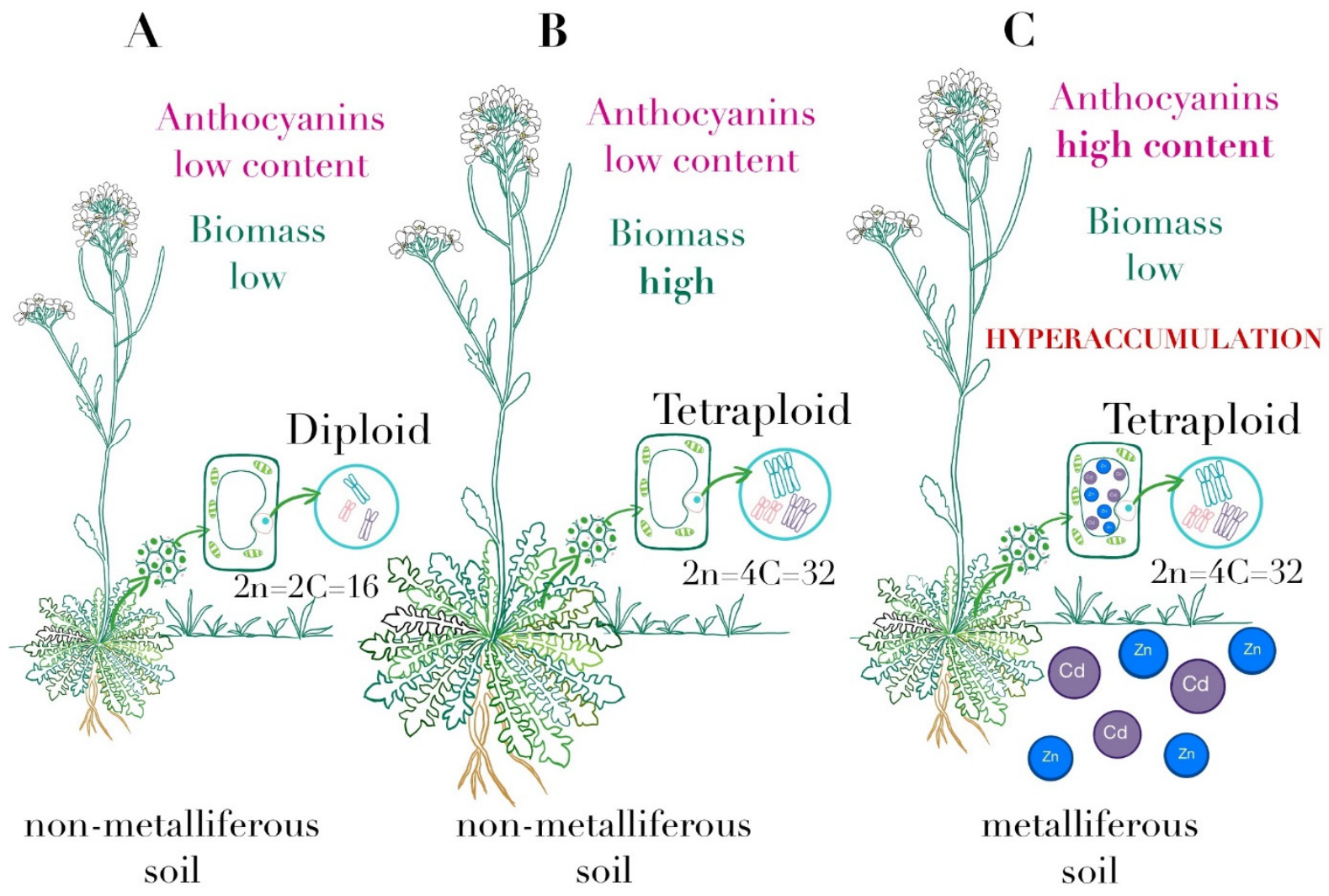

Figure 3. Several features that differ between the populations of A. arenosa. (A) Diploid populations from non-metalliferous sites are characterized by a low anthocyanins content and low biomass. (B) Tetraploid populations from non-metalliferous sites are characterized by low anthocyanins content and high biomass. (C) Tetraploid populations from metalliferous sites show a high content of anthocyanins and low biomass; additionally, they have the ability to hyperaccumulate heavy metals.

Despite the growing scientific interest in A. arenosa species, the mechanism of coping with HMs in the natural habitats of this species is still unknown. Even though $A$. arenosa often occurs in the same sites with $A$. halleri, comparative studies of both species have shown contrasting metal accumulation strategies. In $A$. arenosa, only metallicolous populations exhibited $\mathrm{Zn}$ and $\mathrm{Cd}$ hyperaccumulation, while this trait was observed in both metallicolous and non-metallicolous populations of $A$. halleri $[17,22,35,66]$. The molecular studies indicated that HM hyperaccumulation is associated with a change in the expression level of numerous genes (Table 1). The first stage is the uptake and transport of a metal by the roots. The primary role in this process is played by members of the ZIP family (the zinc-regulated transporter/iron-regulated transporter-like proteins), whose expression is high in the roots and/or shoots of hyperaccumulating plants [45,46,67]. ZIP19 and ZIP23 transporters are mainly responsible for the uptake of zinc by the roots of $A$. halleri and $N$. caerulescens [46]. In non-hyperaccumulator species, the expression of several ZIP genes is low and increases during $\mathrm{Zn}$ deficiency $[46,67]$. In addition, it was found that $\mathrm{Cd}$ treatment induces the higher expression of genes related to Cd uptake and transport in roots (IRT1, 
ZIF1) and shoot (ZIF1 and YSL3), as well as Cd vacuolar sequestration (HMA3) [68]. IRT1 (iron-regulated transporter 1) encoding a low selective Fe-uptake transporter in the root epidermis is also involved in $\mathrm{Zn}, \mathrm{Cd}$ and/or nickel (Ni) uptake [67]. Therefore, it has been shown that different expression levels of these genes in $A$. halleri are associated with the differential accumulation of these metals in shoots $[68,69]$. Subsequently, Zn enters the cortex with the participation of ZIP4 and/or IRT1, and next to the endodermis through IRT3 and ZIP5, ZIP19, ZIP23, transporters [45,46,70]. Due to the presence of Casparian strips, the further transport of $\mathrm{Zn}$ is only possible via ZIP4/ZNT1 transporters. The increased expression of genes encoding these transporters was demonstrated in the roots of both A. halleri and $N$. caerulescens $[46,67,71]$. The next stage is the loading of metals into the xylem, which is mediated by the HM transporter, the HMA4 protein, a plasma membrane ATPase [40,72]. In A. halleri, HMA4 occurs in three copies and shows higher expression (four- to ten-fold) compared to HMA4 in A. thaliana. In A. halleri, this higher expression of $H M A 4$ is crucial for the process of hyperaccumulation and hypertolerance $[46,67,71,73]$. All three copies of HMA4 allow xylem metal loading and distribution to leaves due to the activity of $A$. halleri in vascular tissues. This pump also provides a metal exclusion from sensitive tissues such as the root tip $[67,73]$. The increased expression of HMA4 has been demonstrated not only for A. halleri but also for other hyperaccumulators, including N. caerulescens, S. alfredii and S. plumbizincola [74-76]. The xylem loading process is also carried out by other transporters, such as YSL (yellow stripe-like protein), which are mainly responsible for the transport of $\mathrm{Zn}, \mathrm{Cu}$, manganese $(\mathrm{Mn}), \mathrm{Ni}, \mathrm{Cd}$ and Fe. In addition, the YSL proteins take part in the long-distance transport of metals in the xylem together with the protein FRD3 (ferric reductase defective 3). However, the FRD3 transporter is only responsible for the Fe/Zn translocation in the xylem [46,77-79]. After the metals reach the above-ground organs of a plant, they enter the leaf cells through ZIP4 and ZIP6 proteins [46]. Both proteins were located in the plasma membrane of the $A$. halleri shoots and $S$. alfredi shoots and roots [46,80,81]. In leaves, metals are sequestered and detoxified in vacuoles, where their toxic effects are limited. They reach the vacuole by MTP1 proteins (metal tolerance protein 1). In the hyperaccumulator $A$. halleri, the presence of five copies of MTP1 gene was found, which is strongly expressed both in shoots and roots $[67,71,82,83]$. The high expression of this gene has also been detected in other hyperaccumulators such as $N$. caerulescens and S. alfredii [84,85]. Other important transporters responsible for metals entering into the vacuoles is HMA3. In A halleri, a higher expression level of HMA3 was detected in the mesophyll, whereas $N$. caerulescens had higher expression in the bundle sheath of the veins $[46,79,86]$. Transporters from the HMA family also show a detoxifying function in other hyperaccumulators such as $S$. alfredii and S. plumbizincola $[46,79,87-89]$. Another family of genes involved in vacuole sequestration is the NRAMP gene family (natural resistance-associated macrophage protein). The high expression of NRAMP1, NRAMP3, NRAMP4, and NRAMP5 has been detected in A. halleri and $N$. caerulescens $[46,47,79,81,90-94]$. In A. halleri, the higher expression of the transporter CAX1 (cation-exchanger 1) also seems to be responsible for $\mathrm{Cd}$ hypertolerance $[95,96]$.

Table 1 shows that the function of a large number of genes responsible for metal uptake, xylem leading, long-distance transport or vacuole sequestration have been identified in A. halleri and N. caerulescens. By contrast, in A. arenosa, the expression level of genes related to metal uptake or hypertolerance are still unknown (Table 1). These knowledge gap should be addressed, particularly that several hyperaccumulating $\mathrm{Zn}$ and $\mathrm{Cd}$ populations of $A$. arenosa have recently been found [35]. The first paper, which compares the tolerance to heavy metals in A. arenosa and A. halleri at a genomic level, was published by Preite et al. [3]. They investigated in both species the populations inhabiting the same metalliferous and non-metalliferous sites. Despite the relatively close relationship between $A$. arenosa and A. halleri, a modest degree of gene and functional network convergence between species was demonstrated. The comparison between metallicolous and non-metallicolous populations of $A$. arenosa identified five candidate genes exhibiting selective sweep signatures convergent between both types of populations. These genes are: PHT5;1 (vacuolar Pi 
sequestration), AT1G71210 (pentatricopeptide repeat (PPR) superfamily protein), AXY8 (altered xyloglucan 8; 1,2-a-L-fucosidase), NRPC2 (nuclear RNA polymerase C2), and AT4G19050 (NB-ARC domain-containing disease resistance protein). Surprisingly, none of these genes are responsible for metal uptake or tolerance. Thus, it is evident that further research should be conducted on genes exhibiting selective sweep signatures as well as those connected with metal uptake and tolerance (Table 1).

Table 1. Genes putatively assigned functional roles in mechanisms of heavy metal hyperaccumulation and hypertolerance in Arabidopsis halleri (Ah), Noccaea caerulescens (Nc) and Arabidopsis arenosa (Aa).

\begin{tabular}{|c|c|c|c|c|}
\hline Gene Name & Annotation & Function & Species & Ref \\
\hline ZIP4 & ZIP family, Zn transporter & \multirow{8}{*}{ Metal uptake in cells } & $\mathrm{Ah}, \mathrm{Nc}, \mathrm{Aa} ?$ & {$[71,80,81]$} \\
\hline ZIP5 & ZIP family, Zn transporter & & $\mathrm{Ah}, \mathrm{Nc}, \mathrm{Aa}$ ? & {$[71,80,81]$} \\
\hline ZIP6 & ZIP family, Zn transporter & & $\mathrm{Ah}, \mathrm{Nc}, \mathrm{Aa} ?$ & {$[71,80,93]$} \\
\hline ZIP9 & ZIP family, Zn transporter & & $\mathrm{Ah}, \mathrm{Nc}, \mathrm{Aa} ?$ & {$[71,81,93]$} \\
\hline ZIP19 & ZIP family, Zn transporter & & $\mathrm{Ah}, \mathrm{Nc}, \mathrm{Aa} ?$ & {$[46,67,94]$} \\
\hline ZIP23 & ZIP family, Zn transporter & & $\mathrm{Ah}, \mathrm{Nc}, \mathrm{Aa} ?$ & {$[46,67,94]$} \\
\hline IRT1 & ZIP family, $\mathrm{Fe}^{2+}$ transport protein & & $\mathrm{Ah}, \mathrm{Nc}, \mathrm{Aa} ?$ & {$[69,80,97]$} \\
\hline IRT3 & ZIP family, $\mathrm{Zn}^{2+} / \mathrm{Fe}^{2+}$ transport protein & & $\mathrm{Ah}, \mathrm{Nc}, \mathrm{Aa} ?$ & {$[46,71,98]$} \\
\hline ZNT1 & Zn transporter in Noccaea caerulescens & \multirow{3}{*}{$\begin{array}{l}\text { Metals influx into cells responsible } \\
\text { for xylem loading }\end{array}$} & $\mathrm{Nc}$ & {$[46,99,100]$} \\
\hline ZNT2 & $\mathrm{Zn}$ transporter in Noccaea caerulescens & & $\mathrm{Nc}$ & {$[46,67]$} \\
\hline ZTN5 & Zn transporter in Noccaea caerulescens & & $\mathrm{Nc}$ & {$[46,67,101]$} \\
\hline HMA3 & plasma membrane metal ATPase pump & Metal vacuolar sequestration & Ah, Nc, Aa? & {$[80,86,87,93]$} \\
\hline HMA4 & plasma membrane metal ATPase pump & Metal loading into the xylem & $\mathrm{Ah}, \mathrm{Nc}, \mathrm{Aa}$ ? & {$[73,75,76,86,88]$} \\
\hline MTP1 & Metal tolerance protein & Metal vacuolar sequestration & $\mathrm{Ah}, \mathrm{Nc}, \mathrm{Aa} ?$ & {$[70,82,83,102]$} \\
\hline YSL3 & Fe-NA transporter & \multirow{3}{*}{$\begin{array}{l}\text { Xylem loading and unloading; } \\
\text { long-distance transport }\end{array}$} & $\mathrm{Ah}, \mathrm{Nc}, \mathrm{Aa}$ ? & {$[68,103,104]$} \\
\hline YSL5 & Metal-NA transporter & & Nc, Aa? & {$[103,104]$} \\
\hline YSL6 & Metal-NA transporter & & $\mathrm{Ah}, \mathrm{Nc}, \mathrm{Aa}$ ? & {$[71,104]$} \\
\hline FRD3 & Citrate transporter & Long-distance transport & $\mathrm{Ah}, \mathrm{Nc}, \mathrm{Aa}$ ? & {$[70,71,77,90]$} \\
\hline NRAMP1 & Vacuolar metal transporter & \multirow{4}{*}{$\begin{array}{l}\text { Zn sequestration in the vacuole of } \\
\text { leaf cells }\end{array}$} & Nc, Aa? & {$[46,90,93]$} \\
\hline NRAMP3 & Vacuolar metal transporter & & $\mathrm{Ah}, \mathrm{Nc}, \mathrm{Aa}$ ? & {$[46,90,93,105]$} \\
\hline NRAMP4 & Vacuolar metal transporter & & Nc, Aa? & {$[90,93,105]$} \\
\hline NRAM 5 & Vacuolar metal transporter & & Nc, Aa? & {$[46,90,91]$} \\
\hline
\end{tabular}

\section{Metal Tolerance and Interaction with Soil Microorganism Communities}

Fungi interacting with many plant species has a beneficial effect in the adaptation of plants to various types of environmental stresses, which has been described many times [106-110]. Arabidopsis arenosa was recognized as a non-mycorrhizal species in early studies. Similarly, many other Brassicaceae family species did not show the ability of symbiosis with mycorrhizal fungi $[110,111]$. Nevertheless, it has been shown that both A. arenosa and A. halleri from a serpentine soil occasionally showed the penetration of arbuscular mycorrhizal hyphae into the cortex, but vesicles and arbuscules were not formed [112].

Moreover, studies were conducted on the interaction of the endophytic fungus (Mucor sp.) isolated from $A$. arenosa from the mine wastelands. The studies on plants treated with metals showed several important beneficial aspects of fungus presence, such as improving the water and phosphorus status. The fungus also increased the fresh weight almost two-fold compared with the control. The plants inoculated with Mucor sp. and growing on the mine dump substrate had a three times higher $\mathrm{N}$ content in the shoots than the uninoculated plants $[110,113]$. Additionally, interaction with the fungus led to 
the upregulation of many genes responsible for ethylene metabolism, which resulted in a significant elongation of root hairs. Moreover, the improved transport of $\mathrm{Zn}, \mathrm{Cd}$ and Fe from root to shoot was noted in inoculated plants. This indicates that the interaction with the fungus has a beneficial effect on the management and distribution of toxic metals in plant tissues to minimize the harmful effects in the roots and detoxification in the shoots [110]. Furthermore, the genetic-biochemical diversity was measured in rhizosphere soil of $A$. arenosa and $A$. halleri by denaturing gradient gel electrophoresis (PCR-DGGE). It was found that biodiversity indices in metal-contaminated soil differed between both species and was lower in the A. halleri rhizosphere [114].

\section{Conclusions and Prospects for the Future}

Arabidopsis arenosa has gained interest among scientists for its unique feature of duplicating the whole genome of autotetraploid populations while also existing as a diploid form. Due to this feature, this species has become a model plant for research on the autopolyploidization process. However, this plant species is also able to grow and develop on soils highly contaminated with HM. Moreover, the hyperaccumulation of $\mathrm{Zn}$ and $\mathrm{Cd}$ has been found recently in several tetraploid populations of $A$. arenosa from Poland. Further investigations on the mechanisms of hyperaccumulation of both metals in this plant species are necessary, particularly in countries other than Poland. At present, only tetraploid populations are known as hyperaccumulators. Thus, it is necessary to find out if diploid populations can also grow on metal-contaminated soils and hyperaccumulate $\mathrm{Zn}$ and/or Cd. Although A. arenosa is well known as a pseudo-metallophyte, our knowledge on the mechanism of metal uptake and tolerance in this plant species is very poor, in contrast to A. halleri or N. caerulescens. Thus far, to the best of our knowledge, no research studies have been published for $A$. arenosa, which present the expression level of such genes or gene families as HMA2, HMA3, HMA4, ZIP, NRAMP and MTP, which are crucial for metal tolerance and/or hyperaccumulation. Furthermore, it was found that the tetraploid population from the non-metalliferous site had considerably lower resistance to $\mathrm{Cd}$ compared to the tetraploid metallicolous population. These results show that tetraploidy in A. arenosa is not sufficient for high tolerance to metal toxicity. Thus, investigations are necessary to find out if metal hyperaccumulation and/or tolerance are connected with higher specific gene copy numbers, as shown for A. halleri or N. caerulescens. The above knowledge can be further exploited in high biomass plant species that could be used for phytoremediation or in the production of fortified food.

Author Contributions: Writing—original draft preparation, Ż.G.; writing—review and editing, K.S. and E.M.; supervision, K.S. and E.M. All authors have read and agreed to the published version of the manuscript.

Funding: This research received no external funding.

Data Availability Statement: Not applicable.

Conflicts of Interest: The authors declare no conflict of interest. The funders had no role in the design of the study; in the collection, analyses, or interpretation of data; in the writing of the manuscript, or in the decision to publish the results.

\section{References}

1. Clauss, M.J.; Koch, M.A. Poorly Known Relatives of Arabidopsis thaliana. Trends Plant Sci. 2006, 11, 449-459. [CrossRef]

2. Al-Shehbaz, I.A.; O'Kane, S.L. Taxonomy and phylogeny of Arabidopsis (Brassicaceae). In The Arabidopsis Book; Somerville, C.R., Meyerowitz, E.M., Eds.; American Society of Plant Biologists: Rockville, MD, USA, 2002; Volume 1.

3. Preite, V.; Sailer, C.; Syllwasschy, L.; Bray, S.; Ahmadi, H.; Krämer, U.; Yant, L. Convergent Evolution in Arabidopsis halleri and Arabidopsis arenosa on Calamine Metalliferous Soils. Philos. Trans. R. Soc. Lond. B Biol. Sci. 2019, 374, 20180243. [CrossRef] [PubMed]

4. Szopiński, M.; Sitko, K.; Gieroń, Ż; Rusinowski, S.; Corso, M.; Hermans, C.; Verbruggen, N.; Małkowski, E. Toxic Effects of Cd and $\mathrm{Zn}$ on the Photosynthetic Apparatus of the Arabidopsis halleri and Arabidopsis arenosa Pseudo-Metallophytes. Front. Plant Sci. 2019, 10. [CrossRef] [PubMed] 
5. Ramsey, J.; Schemske, D.W. Neopolyploidy in Flowering Plants. Annu. Rev. Ecol. Evol. Syst. 2002, 33, 589-639. [CrossRef]

6. Peer, W.A.; Mahmoudian, M.; Freeman, J.L.; Lahner, B.; Richards, E.L.; Reeves, R.D.; Murphy, A.S.; Salt, D.E. Assessment of Plants from the Brassicaceae Family as Genetic Models for the Study of Nickel and Zinc Hyperaccumulation. New Phytol. 2006, 172, 248-260. [CrossRef]

7. Kolář, F.; Lučanová, M.; Záveská, E.; Fuxová, G.; Mandáková, T.; Španiel, S.; Senko, D.; Svitok, M.; Kolník, M.; Gudžinskas, Z.; et al. Ecological Segregation Does Not Drive the Intricate Parapatric Distribution of Diploid and Tetraploid Cytotypes of the Arabidopsis arenosa Group (Brassicaceae). Biol. J. Linn. Soc. 2016, 119, 673-688. [CrossRef]

8. Hollister, J.D. Polyploidy: Adaptation to the Genomic Environment. New Phytol. 2015, 205, 1034-1039. [CrossRef]

9. Bento, M.; Tomás, D.; Viegas, W.; Silva, M. Unravelling Genome Dynamics in Arabidopsis Synthetic Auto and Allopolyploid Species. Biol. Plant 2015, 59, 661-670. [CrossRef]

10. Banásová, V.; Ďurišová, E.; Nadubinská, M.; Gurinová, E.; Čiamporová, M. Natural Vegetation, Metal Accumulation and Tolerance in Plants Growing on Heavy Metal Rich Soils. In Bio-Geo Interactions in Metal-Contaminated Soils; Kothe, E., Varma, A., Eds.; Soil Biology; Springer: Berlin/Heidelberg, Germany, 2012; pp. 233-250.

11. Schmickl, R.; Paule, J.; Klein, J.; Marhold, K.; Koch, M.A. The Evolutionary History of the Arabidopsis arenosa Complex: Diverse Tetraploids Mask the Western Carpathian Center of Species and Genetic Diversity. PLoS ONE 2012, 7, 2691. [CrossRef]

12. Yant, L.; Hollister, J.D.; Wright, K.M.; Arnold, B.J.; Higgins, J.D.; Franklin, F.C.H.; Bomblies, K. Meiotic Adaptation to Genome Duplication in Arabidopsis arenosa. Curr. Biol. 2013, 23, 2151-2156. [CrossRef]

13. Wierzbicka, M.; Rostański, A. Microevolutionary Changes in Ecotypes of Calamine Waste Heap Vegetation near Olkusz, Poland: A Review. Acta Biol. Cracov. 2002, 44, 7-19.

14. Bothe, H.; Słomka, A. Divergent Biology of Facultative Heavy Metal Plants. J. Plant Physiol. 2017, 219, 45-61. [CrossRef] [PubMed]

15. Wójcik, M.; Gonnelli, C.; Selvi, F.; Dresler, S.; Rostański, A.; Vangronsveld, J. Chapter One-Metallophytes of Serpentine and Calamine Soils-Their Unique Ecophysiology and Potential for Phytoremediation. In Advances in Botanical Research; Cuypers, A., Vangronsveld, J., Eds.; Phytoremediation; Academic Press: Cambridge, MA, USA, 2017; Volume 83, pp. 1-42.

16. Manara, A.; Fasani, E.; Furini, A.; DalCorso, G. Evolution of the Metal Hyperaccumulation and Hypertolerance Traits. Plant Cell Environ. 2020, 43, 2969-2986. [CrossRef] [PubMed]

17. Sitko, K.; Rusinowski, S.; Kalaji, H.M.; Szopiński, M.; Małkowski, E. Photosynthetic Efficiency as Bioindicator of Environmental Pressure in A. halleri. Plant Physiol. 2017, 175, 290-302. [CrossRef]

18. Przedpełska, E.; Wierzbicka, M. Arabidopsis arenosa (Brassicaceae) from a Lead-Zinc Waste Heap in Southern Poland-A Plant with High Tolerance to Heavy Metals. Plant Soil 2007, 299, 43-53. [CrossRef]

19. Fiałkiewicz, B.; Rostański, A. Morphological Variability of Cardaminopsis halleri (L.) Hayek from Selected Habitats in the Silesian Upland (Southern Poland). Biodiv. Res. Conserv. 2006, 1-2, 34-40.

20. Szarek-Łukaszewska, G.; Grodzinska, K. Vegetation of a Post-Mining Open Pit (Zn/Pb Ores): Three-Year Study of Colonization. Pol. J. Ecol. 2007, 55, 261-282.

21. Szarek-Łukaszewska, G.; Grodzińska, K. Grasslands of a Zn-Pb Post-Mining Area (Olkusz Ore-Bearing Region, S. Poland). Pol. Bot. J. 2011, 56, 245-260.

22. Szopiński, M.; Sitko, K.; Rusinowski, S.; Zieleźnik-Rusinowska, P.; Corso, M.; Rostański, A.; Rojek-Jelonek, M.; Verbruggen, N.; Małkowski, E. Different Strategies of Cd Tolerance and Accumulation in Arabidopsis halleri and Arabidopsis arenosa. Plant Cell Environ. 2020. [CrossRef]

23. Higgins, J.D.; Wright, K.M.; Bomblies, K.; Franklin, C. Cytological Techniques to Analyze Meiosis in Arabidopsis arenosa for Investigating Adaptation to Polyploidy. Front. Plant Sci. 2014, 4. [CrossRef]

24. Lloyd, A.; Bomblies, K. Meiosis in Autopolyploid and Allopolyploid Arabidopsis. Curr. Opin. Plant Biol. 2016, 30, 116-122. [CrossRef] [PubMed]

25. del Pozo, J.C.; Ramirez-Parra, E. Whole Genome Duplications in Plants: An Overview from Arabidopsis. J. Exp. Bot. 2015, 66, 6991-7003. [CrossRef] [PubMed]

26. Hollister, J.D.; Arnold, B.J.; Svedin, E.; Xue, K.S.; Dilkes, B.P.; Bomblies, K. Genetic Adaptation Associated with Genome-Doubling in Autotetraploid Arabidopsis arenosa. PLoS Genet. 2012, 8. [CrossRef] [PubMed]

27. Sebastian, J.; Ravi, M.; Andreuzza, S.; Panoli, A.P.; Marimuthu, M.P.A.; Siddiqi, I. The Plant Adherin AtSCC2 Is Required for Embryogenesis and Sister-Chromatid Cohesion during Meiosis in Arabidopsis. Plant J. 2009, 59, 1-13. [CrossRef]

28. Watanabe, K.; Pacher, M.; Dukowic, S.; Schubert, V.; Puchta, H.; Schubert, I. The Structural Maintenance Of Chromosomes $5 / 6$ Complex Promotes Sister Chromatid Alignment and Homologous Recombination after DNA Damage in Arabidopsis thaliana. Plant Cell 2009, 21, 2688-2699. [CrossRef]

29. Monnahan, P.; Kolář, F.; Baduel, P.; Sailer, C.; Koch, J.; Horvath, R.; Laenen, B.; Schmickl, R.; Paajanen, P.; Šrámková, G.; et al. Pervasive Population Genomic Consequences of Genome Duplication in Arabidopsis arenosa. Nat. Ecol. Evol. 2019, 3, 457-468. [CrossRef]

30. Baduel, P.; Arnold, B.; Weisman, C.M.; Hunter, B.; Bomblies, K. Habitat-Associated Life History and Stress-Tolerance Variation in Arabidopsis arenosa. Plant Physiol. 2016, 171, 437-451. [CrossRef]

31. Selmecki, A.M.; Maruvka, Y.E.; Richmond, P.A.; Guillet, M.; Shoresh, N.; Sorenson, A.L.; De, S.; Kishony, R.; Michor, F.; Dowell, R.; et al. Polyploidy Can Drive Rapid Adaptation in Yeast. Nature 2015, 519, 349-352. [CrossRef]

32. Gerstein, A.C.; Otto, S.P. Ploidy and the Causes of Genomic Evolution. J. Hered. 2009, 100, 571-581. [CrossRef] 
33. Parisod, C.; Holderegger, R.; Brochmann, C. Evolutionary Consequences of Autopolyploidy. New Phytol. 2010, 186, 5-17. [CrossRef]

34. Pollard, A.J.; Reeves, R.D.; Baker, A.J.M. Facultative Hyperaccumulation of Heavy Metals and Metalloids. Plant Sci. 2014, 217-218, 8-17. [CrossRef]

35. Gieroń, Ż.; Sitko, K.; Zieleźnik-Rusinowska, P.; Szopiński, M.; Rojek-Jelonek, M.; Rostański, A.; Rudnicka, M.; Małkowski, E. Ecophysiology of Arabidopsis arenosa, a New Hyperaccumulator of Cd and Zn. J. Hazard. Mater. 2021, 412, 125052. [CrossRef] [PubMed]

36. van der Ent, A.; Baker, A.J.M.; Reeves, R.D.; Pollard, A.J.; Schat, H. Hyperaccumulators of Metal and Metalloid Trace Elements: Facts and Fiction. Plant Soil 2013, 362, 319-334. [CrossRef]

37. Rascio, N.; Navari-Izzo, F. Heavy Metal Hyperaccumulating Plants: How and Why Do They Do It? And What Makes Them so Interesting? Plant Sci. 2011, 180, 169-181. [CrossRef]

38. Brooks, R.R.; Lee, J.; Reeves, R.D.; Jaffré, T. Detection of Nickeliferous Rocks by Analysis of Herbarium Specimens of Indicator Plants. J. Geochem. Explor. 1977, 7, 49-57. [CrossRef]

39. Rascio, N. Metal Accumulation by Some Plants Growing on Zinc-Mine Deposits. Oikos 1977, 29, 250-253. [CrossRef]

40. Krämer, U. Metal Hyperaccumulation in Plants. Annu. Rev. Plant Biol. 2010, 61, 517-534. [CrossRef]

41. Brooks, R.R. Plants That Hyperaccumulate Heavy Metals, Their Role in Phytoremediation, Microbiology, Archaeology, Mineral Exploration and Phytomining; CAB International: Wallingford, UK, 1998.

42. Baker, A.J.M.; McGrath, S.P.; Reeves, R.D.; Smith, J.A.C. Metal hyperaccumulator plants: A review of the ecology and physiology of a biological resource for phytoremediation of metal-polluted soils. In Phytoremediation of Contaminated Soils; Terry, N., Vangronsveld, J., Banuelos, G., Eds.; CRC Press: Boca Raton, FL, USA, 2000; pp. 85-107.

43. Reeves, R.D.; Baker, A.J.M.; Jaffré, T.; Erskine, P.D.; Echevarria, G.; van der Ent, A. A Global Database for Plants That Hyperaccumulate Metal and Metalloid Trace Elements. New Phytol. 2018, 218, 407-411. [CrossRef] [PubMed]

44. Macnair, M.R. The hyperaccumulation of metals by plants. In Advances in Botanical Research; Academic Press: Cambridge, MA, USA, 2003; Volume 40, pp. 63-105.

45. Verbruggen, N.; Hermans, C.; Schat, H. Molecular Mechanisms of Metal Hyperaccumulation in Plants. New Phytol. 2009, 181, 759-776. [CrossRef] [PubMed]

46. Balafrej, H.; Bogusz, D.; Triqui, Z.-E.A.; Guedira, A.; Bendaou, N.; Smouni, A.; Fahr, M. Zinc Hyperaccumulation in Plants: A Review. Plants 2020, 9, 562. [CrossRef] [PubMed]

47. Nadgórska-Socha, A.; Kandziora-Ciupa, M.; Ciepał, R. Element Accumulation, Distribution, and Phytoremediation Potential in Selected Metallophytes Growing in a Contaminated Area. Environ. Monit. Assess. 2015, 187, 441. [CrossRef] [PubMed]

48. Turisová, I.; Štrba, T.; Aschenbrenner, Š.; Andráš, P. Arabidopsis arenosa (L.) Law. On Metalliferous and Non-Metalliferous Sites in Central Slovakia. Bull. Environ. Contam. Toxicol. 2013, 91, 469-474. [CrossRef]

49. Li, T.; Yang, X.; Lu, L.; Islam, E.; He, Z. Effects of Zinc and Cadmium Interactions on Root Morphology and Metal Translocation in a Hyperaccumulating Species under Hydroponic Conditions. J. Hazard. Mater. 2009, 169, 734-741. [CrossRef] [PubMed]

50. Bayçu, G.; Moustaka, J.; Gevrek, N.; Moustakas, M. Chlorophyll Fluorescence Imaging Analysis for Elucidating the Mechanism of Photosystem II Acclimation to Cadmium Exposure in the Hyperaccumulating Plant Noccaea caerulescens. Materials 2018, 11, 2580. [CrossRef]

51. Küpper, H.; Benedikty, Z.; Morina, F.; Andresen, E.; Mishra, A.; Trtílek, M. Analysis of OJIP Chlorophyll Fluorescence Kinetics and QA Reoxidation Kinetics by Direct Fast Imaging. Plant Physiol. 2019, 179, 369-381. [CrossRef]

52. Morina, F.; Küpper, H. Direct Inhibition of Photosynthesis by Cd Dominates over Inhibition Caused by Micronutrient Deficiency in the Cd/Zn Hyperaccumulator Arabidopsis halleri. Plant Physiol. Biochem. 2020, 155, 252-261. [CrossRef]

53. Pogrzeba, M.; Rusinowski, S.; Sitko, K.; Krzyżak, J.; Skalska, A.; Małkowski, E.; Ciszek, D.; Werle, S.; McCalmont, J.P.; Mos, M.; et al. Relationships between Soil Parameters and Physiological Status of Miscanthus x Giganteus Cultivated on Soil Contaminated with Trace Elements under NPK Fertilisation vs. Microbial Inoculation. Environ. Pollut. 2017, 225, 163-174. [CrossRef]

54. Rusinowski, S.; Szada-Borzyszkowska, A.; Zieleźnik-Rusinowska, P.; Małkowski, E.; Krzyżak, J.; Woźniak, G.; Sitko, K.; Szopiński, M.; McCalmont, J.P.; Kalaji, H.M.; et al. How Autochthonous Microorganisms Influence Physiological Status of Zea Mays L. Cultivated on Heavy Metal Contaminated Soils? Environ. Sci. Pollut. Res. 2019, 26, 4746-4763. [CrossRef] [PubMed]

55. Baczek-Kwinta, R.; Juzoń, K.; Borek, M.; Antonkiewicz, J. Photosynthetic Response of Cabbage in Cadmium-Spiked Soil. Photosynthetica 2019, 57, 731-739. [CrossRef]

56. Małkowski, E.; Sitko, K.; Szopiński, M.; Gieroń, Ż.; Pogrzeba, M.; Kalaji, H.M.; Zieleźnik-Rusinowska, P. Hormesis in Plants: The Role of Oxidative Stress, Auxins and Photosynthesis in Corn Treated with Cd or Pb. Int. J. Mol. Sci. 2020, 21, 2099. [CrossRef]

57. Bury, M.; Rusinowski, S.; Sitko, K.; Krzyżak, J.; Kitczak, T.; Możdżer, E.; Siwek, H.; Włodarczyk, M.; Zieleźnik-Rusinowska, P.; Szada-Borzyszkowska, A.; et al. Physiological Status and Biomass Yield of Sida hermaphrodita (L.) Rusby Cultivated on Two Distinct Marginal Lands in Southern and Northern Poland. Ind. Crop. Prod. 2021, 167, 113502. [CrossRef]

58. Rusinowski, S.; Krzyżak, J.; Clifton-Brown, J.; Jensen, E.; Mos, M.; Webster, R.; Sitko, K.; Pogrzeba, M. New Miscanthus Hybrids Cultivated at a Polish Metal-Contaminated Site Demonstrate High Stomatal Regulation and Reduced Shoot Pb and $\mathrm{Cd}$ Concentrations. Environ. Pollut. 2019, 252, 1377-1387. [CrossRef] [PubMed] 
59. Bayçu, G.; Gevrek-Kürüm, N.; Moustaka, J.; Csatári, I.; Rognes, S.E.; Moustakas, M. Cadmium-Zinc Accumulation and Photosystem II Responses of Noccaea caerulescens to Cd and Zn Exposure. Environ. Sci. Pollut. Res. Int. 2017, 24, 2840-2850. [CrossRef]

60. Zhao, F.J.; Lombi, E.; Breedon, T. Zinc Hyperaccumulation and Cellular Distribution in Arabidopsis halleri. Plant Cell Environ. 2000, 23, 507-514. [CrossRef]

61. Muszyńska, E.; Tokarz, K.M.; Dziurka, M.; Labudda, M.; Dziurka, K.; Tokarz, B. Photosynthetic Apparatus Efficiency, Phenolic Acid Profiling and Pattern of Chosen Phytohormones in Pseudometallophyte Alyssum montanum. Sci. Rep 2021, $11,4135$. [CrossRef] [PubMed]

62. Šamec, D.; Linić, I.; Salopek-Sondi, B. Salinity Stress as an Elicitor for Phytochemicals and Minerals Accumulation in Selected Leafy Vegetables of Brassicaceae. Agronomy 2021, 11, 361. [CrossRef]

63. Baek, S.A.; Han, T.J.; Ahn, S.K.; Kang, H.R.; Cho, M.R.; Lee, S.C.; Im, K.H. Effects of Heavy Metals on Plant Growths and Pigment Contents in Arabidopsis thaliana. Plant Pathol. J. 2012, 28, 446-452. [CrossRef]

64. Muszyńska, E.; Labudda, M.; Różańska, E.; Hanus-Fajerska, E.; Znojek, E. Heavy Metal Tolerance in Contrasting Ecotypes of Alyssum montanum. EES 2018, 161, 305-317. [CrossRef] [PubMed]

65. Šamec, D.; Karalija, E.; Šola, I.; Vujčić Bok, V.; Salopek-Sondi, B. The Role of Polyphenols in Abiotic Stress Response: The Influence of Molecular Structure. Plants 2021, 10, 118. [CrossRef]

66. Stein, R.J.; Höreth, S.; de Melo, J.R.F.; Syllwasschy, L.; Lee, G.; Garbin, M.L.; Clemens, S.; Krämer, U. Relationships between Soil and Leaf Mineral Composition Are Element-Specific, Environment-Dependent and Geographically Structured in the Emerging Model Arabidopsis Halleri. New Phytol. 2017, 213, 1274-1286. [CrossRef]

67. Merlot, S.; Garcia de la Torre, V.S.; Hanikenne, M. Physiology and Molecular Biology of Trace Element Hyperaccumulation. In Agromining: Farming for Metals: Extracting Unconventional Resources Using Plants; van der Ent, A., Baker, A.J.M., Echevarria, G., Simonnot, M.-O., Morel, J.L., Eds.; Mineral Resource, Reviews; Springer International Publishing: Cham, Switzerland, 2021; pp. 155-181. ISBN 978-3-030-58904-2.

68. Corso, M.; Schvartzman, M.S.; Guzzo, F.; Souard, F.; Malkowski, E.; Hanikenne, M.; Verbruggen, N. Contrasting Cadmium Resistance Strategies in Two Metallicolous Populations of Arabidopsis halleri. New Phytol. 2018, 218, 283-297. [CrossRef]

69. Schvartzman, M.S.; Corso, M.; Fataftah, N.; Scheepers, M.; Nouet, C.; Bosman, B.; Carnol, M.; Motte, P.; Verbruggen, N.; Hanikenne, M. Adaptation to High Zinc Depends on Distinct Mechanisms in Metallicolous Populations of Arabidopsis halleri. New Phytol. 2018, 218, 269-282. [CrossRef] [PubMed]

70. Van de Mortel, J.E.; Villanueva, L.A.; Schat, H.; Kwekkeboom, J.; Coughlan, S.; Moerland, P.D.; van Themaat, E.V.L.; Koornneef, M.; Aarts, M.G.M. Large Expression Differences in Genes for Iron and Zinc Homeostasis, Stress Response, and Lignin Biosynthesis Distinguish Roots of Arabidopsis Thaliana and the Related Metal Hyperaccumulator Thlaspi Caerulescens. Plant Physiol. 2006, 142, 1127-1147. [CrossRef] [PubMed]

71. Talke, I.N.; Hanikenne, M.; Krämer, U. Zinc-Dependent Global Transcriptional Control, Transcriptional Deregulation, and Higher Gene Copy Number for Genes in Metal Homeostasis of the Hyperaccumulator Arabidopsis halleri. Plant Physiol. 2006, 142, 148-167. [CrossRef]

72. Meyer, C.-L.; Verbruggen, N. The Use of the Model Species Arabidopsis halleri towards Phytoextraction of Cadmium Polluted Soils. New Biotechnol. 2012, 30, 9-14. [CrossRef]

73. Hanikenne, M.; Talke, I.N.; Haydon, M.J.; Lanz, C.; Nolte, A.; Motte, P.; Kroymann, J.; Weigel, D.; Krämer, U. Evolution of Metal Hyperaccumulation Required Cis -Regulatory Changes and Triplication of HMA4. Nature 2008, 453, 391-395. [CrossRef]

74. Zhang, Z.; Yu, Q.; Du, H.; Ai, W.; Yao, X.; Mendoza-Cózatl, D.G.; Qiu, B. Enhanced Cadmium Efflux and Root-to-Shoot Translocation Are Conserved in the Hyperaccumulator Sedum alfredii (Crassulaceae Family). FEBS Lett. 2016, 590, 1757-1764. [CrossRef] [PubMed]

75. Craciun, A.R.; Meyer, C.-L.; Chen, J.; Roosens, N.; De Groodt, R.; Hilson, P.; Verbruggen, N. Variation in HMA4 Gene Copy Number and Expression among Noccaea caerulescens Populations Presenting Different Levels of Cd Tolerance and Accumulation. J. Exp. Bot. 2012, 63, 4179-4189. [CrossRef]

76. Peng, J.-S.; Wang, Y.-J.; Ding, G.; Ma, H.-L.; Zhang, Y.-J.; Gong, J.-M. A Pivotal Role of Cell Wall in Cadmium Accumulation in the Crassulaceae Hyperaccumulator Sedum plumbizincicola. Mol. Plant 2017, 10, 771-774. [CrossRef]

77. Hassan, Z.; Aarts, M.G.M. Opportunities and Feasibilities for Biotechnological Improvement of Zn, Cd or Ni Tolerance and Accumulation in Plants. Environ. Exp. Bot. 2011, 72, 53-63. [CrossRef]

78. Curie, C.; Cassin, G.; Couch, D.; Divol, F.; Higuchi, K.; Le Jean, M.; Misson, J.; Schikora, A.; Czernic, P.; Mari, S. Metal Movement within the Plant: Contribution of Nicotianamine and Yellow Stripe 1-like Transporters. Ann. Bot. 2009, 103, 1-11. [CrossRef]

79. Huang, X.; Duan, S.; Wu, Q.; Yu, M.; Shabala, S. Reducing Cadmium Accumulation in Plants: Structure-Function Relations and Tissue-Specific Operation of Transporters in the Spotlight. Plants 2020, 9, 223. [CrossRef] [PubMed]

80. Becher, M.; Talke, I.N.; Krall, L.; Krämer, U. Cross-Species Microarray Transcript Profiling Reveals High Constitutive Expression of Metal Homeostasis Genes in Shoots of the Zinc Hyperaccumulator Arabidopsis halleri. Plant J. 2004, 37, 251-268. [CrossRef]

81. Gupta, N.; Ram, H.; Kumar, B. Mechanism of Zinc Absorption in Plants: Uptake, Transport, Translocation and Accumulation. Rev. Environ. Sci. Bio/Technol. 2016, 15, 89-109. [CrossRef]

82. Fasani, E.; DalCorso, G.; Varotto, C.; Li, M.; Visioli, G.; Mattarozzi, M.; Furini, A. The MTP1 Promoters from Arabidopsis halleri Reveal Cis-Regulating Elements for the Evolution of Metal Tolerance. New Phytol. 2017, 214, 1614-1630. [CrossRef] [PubMed] 
83. Shahzad, Z.; Gosti, F.; Frérot, H.; Lacombe, E.; Roosens, N.; Saumitou-Laprade, P.; Berthomieu, P. The Five AhMTP1 Zinc Transporters Undergo Different Evolutionary Fates towards Adaptive Evolution to Zinc Tolerance in Arabidopsis halleri. PLoS Genet. 2010, 6, e1000911. [CrossRef]

84. Milner, M.J.; Kochian, L.V. Investigating Heavy-Metal Hyperaccumulation Using Thlaspi Caerulescens as a Model System. Ann. Bot. 2008, 102, 3-13. [CrossRef]

85. Zhang, M.; Senoura, T.; Yang, X.; Nishizawa, N.K. Functional Analysis of Metal Tolerance Proteins Isolated from Zn/Cd Hyperaccumulating Ecotype and Non-Hyperaccumulating Ecotype of Sedum alfredii Hance. FEBS Lett. 2011, 585, 2604-2609. [CrossRef]

86. Mishra, S.; Mishra, A.; Küpper, H. Protein Biochemistry and Expression Regulation of Cadmium/Zinc Pumping ATPases in the Hyperaccumulator Plants Arabidopsis halleri and Noccaea caerulescens. Front. Plant Sci. 2017, 8, 835. [CrossRef]

87. Liu, H.; Zhao, H.; Wu, L.; Liu, A.; Zhao, F.-J.; Xu, W. Heavy Metal ATPase 3 (HMA3) Confers Cadmium Hypertolerance on the Cadmium/Zinc Hyperaccumulator Sedum plumbizincicola. New Phytol. 2017, 215, 687-698. [CrossRef]

88. Zhang, J.; Zhang, M.; Shohag, M.J.I.; Tian, S.; Song, H.; Feng, Y.; Yang, X. Enhanced Expression of SaHMA3 Plays Critical Roles in Cd Hyperaccumulation and Hypertolerance in Cd Hyperaccumulator Sedum alfredii Hance. Planta 2016, 243, 577-589. [CrossRef]

89. Zhao, H.; Wang, L.; Zhao, F.-J.; Wu, L.; Liu, A.; Xu, W. SpHMA1 Is a Chloroplast Cadmium Exporter Protecting Photochemical Reactions in the Cd Hyperaccumulator Sedum plumbizincicola. Plant Cell Environ. 2019, 42, 1112-1124. [CrossRef] [PubMed]

90. Krämer, U.; Talke, I.N.; Hanikenne, M. Transition Metal Transport. FEBS Lett. 2007, 581, 2263-2272. [CrossRef] [PubMed]

91. Weber, M.; Harada, E.; Vess, C.; Roepenack-Lahaye, E.V.; Clemens, S. Comparative Microarray Analysis of Arabidopsis thaliana and Arabidopsis halleri Roots Identifies Nicotianamine Synthase, a ZIP Transporter and Other Genes as Potential Metal Hyperaccumulation Factors. Plant J. 2004, 37, 269-281. [CrossRef]

92. Lanquar, V.; Lelièvre, F.; Bolte, S.; Hamès, C.; Alcon, C.; Neumann, D.; Vansuyt, G.; Curie, C.; Schröder, A.; Krämer, U.; et al. Mobilization of Vacuolar Iron by AtNRAMP3 and AtNRAMP4 Is Essential for Seed Germination on Low Iron. EMBO J. 2005, 24, 4041-4051. [CrossRef] [PubMed]

93. Halimaa, P.; Lin, Y.-F.; Ahonen, V.H.; Blande, D.; Clemens, S.; Gyenesei, A.; Häikiö, E.; Kärenlampi, S.O.; Laiho, A.; Aarts, M.G.M.; et al. Gene Expression Differences between Noccaea caerulescens Ecotypes Help to Identify Candidate Genes for Metal Phytoremediation. Environ. Sci. Technol. 2014, 48, 3344-3353. [CrossRef]

94. Assunção, A.G.L.; Herrero, E.; Lin, Y.-F.; Huettel, B.; Talukdar, S.; Smaczniak, C.; Immink, R.G.H.; van Eldik, M.; Fiers, M.; Schat, H.; et al. Arabidopsis thaliana Transcription Factors BZIP19 and BZIP23 Regulate the Adaptation to Zinc Deficiency. Proc. Natl. Acad. Sci. USA 2010, 107, 10296-10301. [CrossRef]

95. Baliardini, C.; Meyer, C.-L.; Salis, P.; Saumitou-Laprade, P.; Verbruggen, N. CATION EXCHANGER1 Cosegregates with Cadmium Tolerance in the Metal Hyperaccumulator Arabidopsis halleri and Plays a Role in Limiting Oxidative Stress in Arabidopsis spp. Plant Physiol. 2015, 169, 549-559. [CrossRef]

96. Ahmadi, H.; Corso, M.; Weber, M.; Verbruggen, N.; Clemens, S. CAX1 Suppresses Cd-Induced Generation of Reactive Oxygen Species in Arabidopsis halleri. Plant Cell Environ. 2018, 41, 2435-2448. [CrossRef]

97. Corso, M.; Torre, V.S.G. de la Biomolecular Approaches to Understanding Metal Tolerance and Hyperaccumulation in Plants. Metallomics 2020, 12, 840-859. [CrossRef]

98. Lin, Y.-F.; Liang, H.-M.; Yang, S.-Y.; Boch, A.; Clemens, S.; Chen, C.-C.; Wu, J.-F.; Huang, J.-L.; Yeh, K.-C. Arabidopsis IRT3 Is a Zinc-Regulated and Plasma Membrane Localized Zinc/Iron Transporter. New Phytol. 2009, 182, 392-404. [CrossRef] [PubMed]

99. Lin, Y.-F.; Hassan, Z.; Talukdar, S.; Schat, H.; Aarts, M.G.M. Expression of the ZNT1 Zinc Transporter from the Metal Hyperaccumulator Noccaea caerulescens Confers Enhanced Zinc and Cadmium Tolerance and Accumulation to Arabidopsis thaliana. PLoS ONE 2016, 11, e0149750. [CrossRef] [PubMed]

100. Milner, M.J.; Craft, E.; Yamaji, N.; Koyama, E.; Ma, J.F.; Kochian, L.V. Characterization of the High Affinity Zn Transporter from Noccaea caerulescens, NcZNT1, and Dissection of Its Promoter for Its Role in Zn Uptake and Hyperaccumulation. New Phytol. 2012, 195, 113-123. [CrossRef] [PubMed]

101. Kozhevnikova, A.D.; Seregin, I.V.; Gosti, F.; Schat, H. Zinc Accumulation and Distribution over Tissues in Noccaea caerulescens in Nature and in Hydroponics: A Comparison. Plant Soil 2017, 411, 5-16. [CrossRef]

102. Meyer, C.-L.; Pauwels, M.; Briset, L.; Godé, C.; Salis, P.; Bourceaux, A.; Souleman, D.; Frérot, H.; Verbruggen, N. Potential Preadaptation to Anthropogenic Pollution: Evidence from a Common Quantitative Trait Locus for Zinc and Cadmium Tolerance in Metallicolous and Nonmetallicolous Accessions of Arabidopsis halleri. New Phytol. 2016, 212, 934-943. [CrossRef] [PubMed]

103. Gendre, D.; Czernic, P.; Conéjéro, G.; Pianelli, K.; Briat, J.-F.; Lebrun, M.; Mari, S. TcYSL3, a Member of the YSL Gene Family from the Hyper-Accumulator Thlaspi caerulescens, Encodes a Nicotianamine-Ni/Fe Transporter. Plant J. 2007, 49, 1-15. [CrossRef]

104. Waters, B.M.; Chu, H.-H.; DiDonato, R.J.; Roberts, L.A.; Eisley, R.B.; Lahner, B.; Salt, D.E.; Walker, E.L. Mutations in Arabidopsis Yellow Stripe-Like1 and Yellow Stripe-Like3 Reveal Their Roles in Metal Ion Homeostasis and Loading of Metal Ions in Seeds. Plant Physiol. 2006, 141, 1446-1458. [CrossRef]

105. Oomen, R.J.F.J.; Wu, J.; Lelièvre, F.; Blanchet, S.; Richaud, P.; Barbier-Brygoo, H.; Aarts, M.G.M.; Thomine, S. Functional Characterization of NRAMP3 and NRAMP4 from the Metal Hyperaccumulator Thlaspi caerulescens. New Phytol. 2009, 181, 637-650. [CrossRef] 
106. Brotman, Y.; Landau, U.; Cuadros-Inostroza, Á.; Takayuki, T.; Fernie, A.R.; Chet, I.; Viterbo, A.; Willmitzer, L. Trichoderma-Plant Root Colonization: Escaping Early Plant Defense Responses and Activation of the Antioxidant Machinery for Saline Stress Tolerance. PLoS Pathog. 2013, 9, e1003221. [CrossRef]

107. Li, T.; Liu, M.J.; Zhang, X.T.; Zhang, H.B.; Sha, T.; Zhao, Z.W. Improved Tolerance of Maize (Zea Mays L.) to Heavy Metals by Colonization of a Dark Septate Endophyte (DSE) Exophiala Pisciphila. Sci. Total Environ. 2011, 409, 1069-1074. [CrossRef]

108. Rozpądek, P.; Wężowicz, K.; Stojakowska, A.; Malarz, J.; Surówka, E.; Sobczyk, Ł.; Anielska, T.; Ważny, R.; Miszalski, Z.; Turnau, K. Mycorrhizal Fungi Modulate Phytochemical Production and Antioxidant Activity of Cichorium intybus L. (Asteraceae) under Metal Toxicity. Chemosphere 2014, 112, 217-224. [CrossRef]

109. Hiruma, K.; Gerlach, N.; Sacristán, S.; Nakano, R.T.; Hacquard, S.; Kracher, B.; Neumann, U.; Ramírez, D.; Bucher, M.; O’Connell, R.J.; et al. Root Endophyte Colletotrichum tofieldiae Confers Plant Fitness Benefits That Are Phosphate Status Dependent. Cell 2016, 165, 464-474. [CrossRef] [PubMed]

110. Rozpądek, P.; Domka, A.M.; Nosek, M.; Ważny, R.; Jędrzejczyk, R.J.; Wiciarz, M.; Turnau, K. The Role of Strigolactone in the Cross-Talk Between Arabidopsis thaliana and the Endophytic Fungus Mucor sp. Front. Microbiol. 2018, 9. [CrossRef] [PubMed]

111. Pawłowska, T.E.; Błaszkowski, J.; Rühling, Å. The Mycorrhizal Status of Plants Colonizing a Calamine Spoil Mound in Southern Poland. Mycorrhiza 1997, 6, 499-505. [CrossRef]

112. Regvar, M.; Vogel, K.; Irgel, N.; Wraber, T.; Hildebrandt, U.; Wilde, P.; Bothe, H. Colonization of Pennycresses (Thlaspi spp.) of the Brassicaceae by Arbuscular Mycorrhizal Fungi. J. Plant Physiol. 2003, 160, 615-626. [CrossRef]

113. Domka, A.; Rozpądek, P.; Ważny, R.; Turnau, K. Mucor Sp.-An Endophyte of Brassicaceae Capable of Surviving in Toxic Metal-Rich Sites. J. Basic Microbiol. 2019, 59, 24-37. [CrossRef] [PubMed]

114. Borymski, S.; Cycoń, M.; Beckmann, M.; Mur, L.A.J.; Piotrowska-Seget, Z. Plant Species and Heavy Metals Affect Biodiversity of Microbial Communities Associated with Metal-Tolerant Plants in Metalliferous Soils. Front. Microbiol. 2018, 9. [CrossRef] [PubMed] 